\title{
CHILDREN'S PERCEPTIONS OF LOCAL RELIGIOUS SITES IN RURAL CENTRAL EUROPE: CASE STUDIES IN THE CZECH-POLISH AND POLISH-SLOVAK BORDERLAND ${ }^{1}$
}

\begin{abstract}
This study focuses on the local identities of children living in rural towns of Czechia, Poland and Slovakia. Cognitive maps, drawn by elementary school students in geographically proximate municipalities near international borders, provide a means of investigating the significance of local religious sites in the minds of young people. This research successfully examines everyday interactions between the subjects and their local landscape. It seeks to highlight religious elements of local identities.

The methods employed in this research present a more humanistic and qualitative approach, shedding light on the daily experiences of children in rural settings. Recognizing the inclusion and even the placement and artistic details of a religious site in a child-drawn map is a powerful way to move research "beyond the "officially sacred". The methods also allow for a blending of both passive - including a religious site in a cognitive map - and active - ranking a religious site among the top three important places - declarations of a religious element within local, territorial identity.

This study demonstrates how children use elements of the local religious landscape in constructing and re-constructing their community identity. The two Slovak municipalities showed the greatest affinity for religious elements among the expressions of local identity (children's cognitive maps). Poland's municipalities ranked in the middle and the two Czech municipalities scored lowest in terms of religious sites being considered important to the research participants.
\end{abstract}

Keywords: children's perceptions, religious sites, rural Central Europe, religious identity.

\section{Introduction}

Local territorial identities are an important facet of community life. Humans tend to acquire a sense of belonging and pride from familiar surroundings and familiar faces. Among other things, people often recognize visual elements of the

${ }^{1}$ This work was supported by the (Grant Agency of the Czech Republic) under Grant (number 17-08370S). 
local landscape as symbols of their community. Such symbols could be physical landforms - mountains or interesting rock formations - or prominent man-made structures - buildings or infrastructure.

Religious structures, in particular, can be a culturally significant element of the landscapes that contribute to local territorial identities. Religion has long been an important dimension of Central Europe's cultural traditions. And while its role and overall significance appears to be shifting due to broad societal changes (Wilford 2010), religion continues to serve as a component of local, regional and even national identities (Reeves 2015).

This study focuses on the importance that young people ascribe to religious sites in their own community. We explore two model regions and compare similar, rural towns on both sides of the borders between Czechia and Poland and between Slovakia and Poland. Relying on cognitive maps drawn by students in the fourth and eighth grade levels (10 to 14 years), we determine whether religious structures appear in the children's maps and what relative importance is attributed to such structures. Student created maps enable us to explore the degree to which international borders and religious and cultural differences among Czech, Polish and Slovak societies are reflected in the children's perceptions.

We chose to focus this study of local religious identity on young people for two reasons. The first was accessibility. Through schools it is possible to access and conduct research with groups of children that fairly accurately represent the communities in which the schools are located. The second was our desire to view local communities through the minds of their inheritors - the rising generation. Children seem to be less conditioned or inhibited by social norms (Hemming, Madge 2011). Their responses provide clearer insights into present conditions as well as the immediate future of local identities for the communities studied.

We seek to answer the following questions concerning religious sites in local communities.

- Do traditionally important religious sites have meaning for today's children?

- Do perceptions of religious sites differ noticeably among children living in different model areas and on different sides of international borders?

\section{The role of post-secularism and religious identity in the perception of sacred sites}

A number of recent studies focus on religious affiliation but fail to explore other dimensions of religiosity and religious identity. Post-secular society has experienced a transformation of religious identity accompanied by a general increase in the significance of religion and religious identities (Hammond 1988; King 2003). People are now more likely to declare their faith and religious organizations have become an integral part of the public square as well as its emerging virtual and 
digital spaces. Furthermore, religion continues to play a significant role in the lives of many individuals, with religious services still accompanying important life transitions. Religion has acquired more influence in the daily lives of its practitioners and impacts their spatial behaviour, decision making, and their motivations (Klingorová 2016). Because religion now enjoys a greater amount of respect that it did just a few years ago in more strictly secular societies, believers find it easier to express their identity in public. This is sometimes described as a greater institutionalisation of religious life (Wilford 2010). Post-secularism also transforms the various forms in which religious identity depends on secular public institutions and alters its relationship with the democratic public sphere.

The religious landscapes of Europe, as a whole, and of Czechia, Poland and Slovakia have become significantly more diverse (Havlíček 2014) due to immigration, the decline of traditional churches and the growth of smaller, predominantly Christian communities and new religious movements. The presence of new religious communities can be seen in the emergence of new, often visually distinct, places of worship which transform urban space. Large cities tend to be more secularised and their religions more diversified than rural areas (due to a more liberal atmosphere, rationalisation, less social control, more options for leisure activities, more personal approaches to spirituality - Chromý, Jančák, Marada, Havlíček 2011; Potančoková, Berghammer 2015). Moreover, the religious landscape of Czechia, Slovakia and Poland is in many ways unique (Očovsky 1995; Bilska-Wodecka 2006; Havlíček, Hupková 2008), at least in a European context. The religious dimension of this region's landscapes and societies has been significantly altered by communist regimes which sought to remove religious expression from public life. After 1989, religion has regained significance within Czech, Slovak, and Polish societies. This resurgence has been accompanied increased heterogeneity (Bilska-Wodecka 2005; Havlíček, Hupková 2008; Havlíček, Hupková, Smržová 2009; Havlíček, Klingorová 2018; Zachar Podolinska, Tížik, Majo 2019). Along with the rest of Central and Eastern Europe, these three countries experienced a revival of religious life (Henkel 2014), which has found expressions in the religious landscape (not only) through the emergence of new sacral structures (Havlíček, Hupková 2013; Havlíček, Klingorová 2018).

Despite noticeable influences from Christian culture and tradition, Czech society remains predominantly secular. Comparative international studies help to illustrate this point. Special Eurobarometer 225, compiled by the European Union in 2005, posed the question: "Which of the following statements comes closest to your beliefs?" While $80 \%$ of those questioned in Poland selected the statement "I believe there is a God," only $19 \%$ of Czech respondents and $61 \%$ of Slovak respondents professed a belief in God. A more recent study, the Global Religious Landscape (Pew Research Center 2012), published a measure of people unaffiliated with any religion for the three countries in this study. Czechia was 
quite high in this measure at 76\% (Hamplová (2013) describes an even higher percentage - 79.3 - claiming no affiliation to institutionalized religion). In contrast, $14 \%$ of Slovak respondents and a mere $6 \%$ of Polish participants claimed no religious affiliation. Czechia does however contain regions - primarily rural areas - where the percentage of Christians (Catholics, Protestants) remains high (Havlíček, Hupková 2008). Similarly, rural areas in Poland and Slovakia tend to show greater affinity for traditional Christianity.

These vast differences at the country level are likely indicative of significant regional differentiation in religious landscapes and the way that such landscapes are experienced and perceived. These possible differences along with curiosity regarding the aforementioned aspects of post-secularism led us to conduct research into young people's perceptions in rural border regions of Czechia, Poland and Slovakia.

\section{Methods}

It is difficult to ascertain how people really feel about their everyday surroundings and any attempt to measure such feelings and impressions presents additional uncertainties. In such a situation, it is best for researchers to proceed with a carefully defined method and then allow the method to shed what light it can on the research questions. Drawing on other studies using cognitive maps (Ellard 2015), we developed a method that can be effectively used to gather information on the places that people consider important in a locality they are familiar with. This method can be used to explore a wide variety of topical interests and various subsets of communities. In this case, the method focuses on children's views of religious structures in carefully selected towns.

To gather information on children's perceptions of their hometowns, we visited elementary schools and collected cognitive maps from fourth and eighth grade children. Initially, we had intended to use age as a different avenue for comparing results. However, due to limitations in the responses collected, age-based comparison is not feasible with this particular study.

We gave each student a blank sheet of white paper. Next, we - or the classroom teacher - gave students the following instructions.

1. Draw a map of your hometown that shows places that are important to you.

2. After your map is drawn, add numbers next to your important places. Place a number one by the most important, two for the second most important, etc.

3. Label your important places, either directly on the map or in a numbered list.

Tell what the place is and why it is important to you.

Beyond the prepared instructions, a researcher or teacher must not give more information or examples, to minimize any influence - even unintentional influence - that additional examples could provide. This can be difficult, particularly with young children, but there is great value in being consistent and impartial. In 
the elementary school setting, we found it very helpful to talk with the teacher beforehand to explain the instructions and the need to avoid providing examples or otherwise directing students' thoughts and preferences.

We discovered several instances where students that sat next to or near one another produced remarkably similar maps. It was apparent that one or both students took inspiration from their neighbor's map. We did not design the study in a way to effectively avoid this. We did consistently encourage students to submit their own work, reminding them that there were no wrong ways to create their own maps.

\section{Selection of study sites}

This study focuses on six communities in two distinct model areas as depicted in Figure 2. As the intent of the study is to explore perceptions regarding religious sites and to make cross-border comparisons of these perceptions, the defined model areas and selected communities had to match certain criteria. Within the model areas, we sought out communities that were similar in population and that were geographically proximate, but which represented opposite sides of an international border. Moreover, we intentionally picked settlements that were home to significant religious sites.

The case study in the Czech-Polish borderland includes three towns - two Czech and one Polish - in the Neisse-Nisa-Nysa Euroregion, a recognized region for cross-border cooperation among Czechia, Germany and Poland. The towns have similar populations (see Table 1 below) and each has a regionally significant religious site. We refer to this model area as Karpacz, the name of the largest of the three towns.

Ladomírová has the largest population of the case study in the Polish-Slovak borderland and thereby earns the distinction of being its namesake. This area includes two villages from eastern Slovakia and a third from across the border in Poland. Churches found in the Slovak villages are part of a UNESCO heritage site describing old wooden churches that have been carefully preserved. The nearby Polish village of Tylawa is similar in size and has its own prominent Catholic church. In comparison to the Karpacz area, Ladomírová has much smaller populations and is significantly farther to the East (Fig. 1).

The small and rural nature of the towns we conducted research in created some difficulties. We were limited in where we could conduct research by the presence or absence of elementary schools. Yet, even the presence of a school was not an assurance that it would include both fourth and eighth grade classes. Ladomírová only has grades one through five in its school while the school we visited in Tylawa only has higher elementary grades. As in other rural areas, many students commute to the selected elementary schools from the surrounding area. 


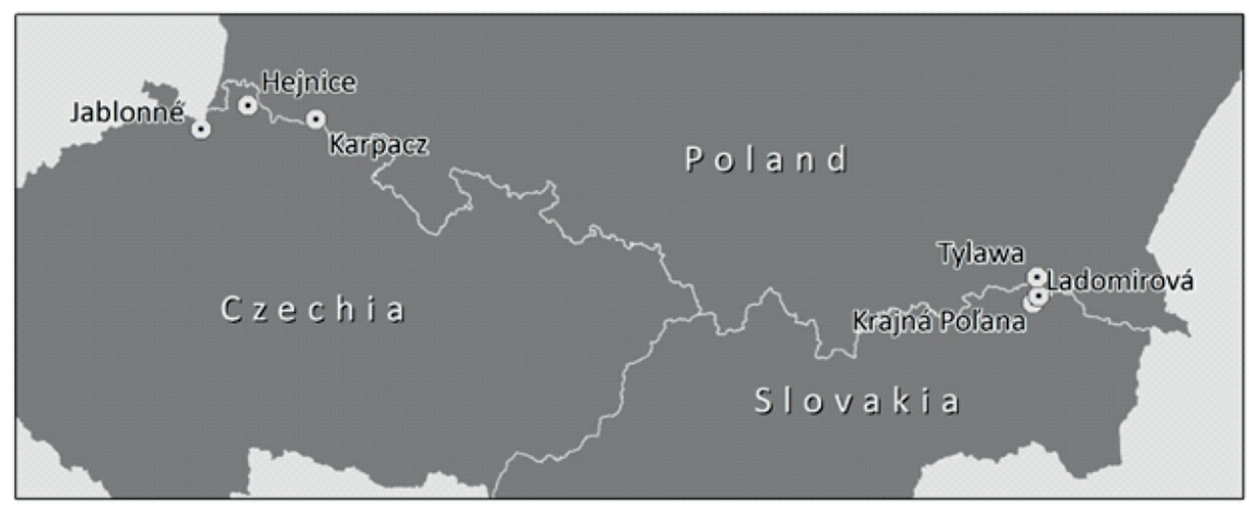

Fig. 1. Location of communities included in the study

Source: authors.

Some student maps do not describe the target community, as we had envisioned it, but instead portray a different nearby settlement.

In the end, we decided to use all the maps we received from the six elementary schools, regardless of whether they depicted one of the selected communities or another village that happens to send students to the same school. From what we could ascertain, these additional villages include their own religious structures and the students had similar choices about what to include or exclude from their maps.

\section{Determining a score}

To compare the various communities with one another, we developed a score that accounts for all religious sites depicted on student maps and includes multipliers for any religious sites ranked in the top three "most important" places. The score includes two simple counts, one describing all maps that depict a religious structure and one describing all maps that rank a religious structure - with any number - as an important place. All maps that have a religious structure labelled as the number one important place are counted and multiplied by three. Maps ranking a religious structure at number two are counted and multiplied by two, while those ranking a religious structure with number three are counted and multiplied by one. These various counts and multipliers are added together for a given town and then divided by the total number of maps collected in that town. Expressed as a formula the score looks like this:

$\mathrm{SCORE}=\frac{\text { maps depicting } \mathrm{RS}+\text { maps ranking } \mathrm{RS}+\left(3^{*} \text { no. of } 1^{\text {st }} \text { rankings }\right)+\left(2^{*} \text { no. of } 2^{\text {nd }} \text { rankings }\right)+\text { no. of } 3^{\text {rd }} \text { rankings }}{\text { Total maps in group }}$

The score is set up in such a way as to account for maps that depict religious structures without ranking them as important as well as maps with any ranking 
assigned to religious structures, regardless of whether this ranking is within the top three. Maps with religious structures ranked among the top three important places are counted and multiplied again to reflect the added significance that their creators have attributed to a religious site.

The same maps can be counted multiple times in the formula. For example, a map in which a religious structure is ranked with number one as an important place will be counted three different times - once as a map depicting a religious structure, once as a map ranking a religious structure and once as a map ranking a religious structure with number one - with the last of these being multiplied by three. Such a map would receive a score of five points that could then be averaged with others to describe a population sample.

We had a few cases, in which the same map had multiple religious structures ranked among the top three important places. These maps were only counted once in the depicting and ranking counts, but they did receive additional points in multipliers for first, second or third rankings. In theory, a single map could bring as many as eight points into the calculation of a group average score. The highest we observed was six points from a single map (religious structures ranked first and third).

The research described herein faces a number of imperfections. The populations and their representative samples are not equivalent; in some cases, they are not even close. The towns and villages differ from one another, as do their respective religious sites. The instructions were not always delivered in precisely the same way and students did not always work independently to complete their own cognitive maps. In spite of all this, we are pleased with the outcome and feel that the resulting student maps provide many insights into children's perceptions of their local landscapes.

\section{Findings}

Table 1 shows the six communities that were included in the study, two each from Czechia, Poland and Slovakia. The table depicts the division into the model areas of Karpacz and Ladomírová. It also describes the population - from the 2011 census, the number of maps we collected and analyzed (sample size), and the average score for each community.

Data on the populations of the six communities shed light on how the two model areas differ from one another. The three communities in the Karpacz group have populations in the thousands and are officially classified as towns. Krajná Pol'ana and Ladomírová are the primary population centers of their respective municipalities (they are not towns), while Tylawa is merely a village within the larger Dukla municipality. The three villages are quite small, particularly Tylawa and Krajná Pol'ana. 
Table 1. Comparison of the six studied communities

\begin{tabular}{|c|c|c|c|c|c|}
\hline $\begin{array}{c}\text { Case study } \\
\text { area } \\
\end{array}$ & Country & Municipality/village & Population & $\begin{array}{l}\text { Sample } \\
\text { size }\end{array}$ & Score \\
\hline \multirow{3}{*}{$\begin{array}{l}\text { Czech-Polish } \\
\text { borderland }\end{array}$} & \multirow{2}{*}{ Czechia } & Hejnice & 2696 & 68 & 1.059 \\
\hline & & Jablonné v Podještědí & 3754 & 63 & 0.556 \\
\hline & \multirow{2}{*}{ Poland } & Karpacz & 5026 & 30 & 1.6 \\
\hline \multirow{3}{*}{$\begin{array}{l}\text { Polish-Slovak } \\
\text { borderland }\end{array}$} & & Tylawa & 381 & 15 & 1.667 \\
\hline & \multirow{2}{*}{ Slovakia } & Krajná Pol'ana & 213 & 22 & 2.955 \\
\hline & & Ladomírová & 991 & 10 & 3.0 \\
\hline
\end{tabular}

Source: all populations are from the respective 2011 national censuses.

Sample sizes for the various communities differ substantially. As mentioned above, the school we visited in Tylawa did not have fourth grade students, while Ladomírová's elementary school has fourth grade but not eighth grade. The study would have benefitted from greater attention to the availability of students in the desired grade levels and stricter expectations concerning sample size.

All communities in the Karpacz group show lower scores than those in the Ladomírová group. The larger populations in the Karpacz area help to explain this, as there is simply a greater variety of things that could be included in student maps and labelled as important. We discuss this in greater detail below (see Table 2).

Considering the larger region of Central Europe, there is a general trend of increasing religiosity from west to east (Tomka 2005). This also aids in explaining the higher scores found in the populations in the Ladomírová group as they are located significantly farther east (see Figure 1). However, the very small difference between the scores for the two Polish communities, despite the geographical distance that separates them, seems to go against the notion of a west-east gradient.

In terms of comparing the three national societies, both scores from Slovakia are higher than the scores from Poland, which in turn are higher than those in Czechia (see Table 1). Slovak children appear more inclined to declare the importance of religious sites in their own community than those in Poland or Czechia, while the Czech children appear quite secular in comparison. These findings are in line with other recent studies of territorial identities in this area, in which Slovakia showed the highest level of religious identity followed by Poland and then by Czechia (Reeves 2015).

To further understand patterns in the ways children viewed their own community and the types of places important to them, we examined the top six important places from each map and placed these into categories. Not surprisingly, "my own home" was the most frequent category, appearing on almost every map. Other popular categories include friends' or relatives' home, recreation (parks, 
playgrounds) and natural landmarks. Table 2 shows how many maps from each population show a religious site labelled as the first, second or third most important place. In contrast, it also has a count of commercial, public and cultural sites ranked in any of the top three spots. This count includes several more narrowly defined categories: public services (police stations, post offices, municipal offices), retail, cultural (movie theaters, pubs) and some recreational opportunities -i.e. not parks and playgrounds, but ski slopes, gyms and swimming pools. All of these counts are shown both as raw numbers from the various community samples as well as normalized ratios (number/sample size) that are comparable across the six communities.

The Karpacz group has higher ratios for the commercial, public and cultural sites and, apart from Karpacz's second and third rankings, much lower ratios for religious sites. This information corroborates the idea that the larger towns of the Karpacz model area provide a wider variety of places for children to select as their important places. The villages of the Ladomírová group tend to have much higher ratios in the religious site rankings.

With its row of totals at the bottom, Table 2 presents an opportunity to make comparisons against the entire collection of maps from these six communities. Ratios from any of the six communities can be easily compared with the overall ratio. It is clear from this data, for example, that Karpacz is above average in terms of maps ranking a religious site as second or third most important. The overall numbers show that maps ranking a religious site in the third most important slot (23) are slightly more common than those awarding a second rank (20), while religious sites depicted as the most important place are quite rare (11 from 208 total maps).

Table 2. Details of high-ranking religious sites and commercial, public and cultural sites by community

\begin{tabular}{|c|c|c|c|c|c|c|c|c|}
\hline \multirow{3}{*}{ Municipalty/village } & \multicolumn{6}{|c|}{ Religious sites } & \multirow{2}{*}{\multicolumn{2}{|c|}{$\begin{array}{c}\text { Commercial, } \\
\text { public and } \\
\text { cultural sites }\end{array}$}} \\
\hline & \multicolumn{2}{|c|}{$1^{\text {st }}$ rankings } & \multicolumn{2}{|c|}{$2^{\text {nd }}$ rankings } & \multicolumn{2}{|c|}{$3^{\text {rd }}$ rankings } & & \\
\hline & no. & ratio & no. & ratio & no. & ratio & no. & ratio \\
\hline Hejnice & 3 & 0.044 & 2 & 0.029 & 5 & 0.074 & 55 & 0.809 \\
\hline Jablonné v Podještědí & 1 & 0.016 & 3 & 0.048 & 1 & 0.016 & 32 & 0.508 \\
\hline Karpacz & 1 & 0.033 & 3 & 0.100 & 6 & 0.200 & 27 & 0.900 \\
\hline Tylawa & 0 & 0 & 4 & 0.267 & 0 & 0 & 5 & 0.333 \\
\hline Krajná Pol’ana & 3 & 0.136 & 6 & 0.273 & 9 & 0.409 & 9 & 0.409 \\
\hline Ladomírová & 3 & 0.300 & 2 & 0.200 & 2 & 0.200 & 5 & 0.500 \\
\hline Totals & 11 & 0.053 & 20 & 0.096 & 23 & 0.111 & 133 & 0.639 \\
\hline
\end{tabular}

Source: authors' calculations. 


\section{Qualitative findings}

Cognitive maps collected in this way have great potential for qualitative research. Many inferences can be made from the way things are depicted and arranged on a map that is drawn by a research participant on a blank piece of paper.

This first map, from a fourth-grade student in Hejnice and presented as Figure 2, seems to place important things closer to the middle. "My home" [můj domov] is drawn near the center with great detail. The church [kostel] is also near the center of the map and labelled as the third most important place, behind home and school. We were impressed with the detail that many students used to depict the sacral landscapes that we were interested in seeing in their maps. The Kostel Navštiveni Panny Marie [Church of the Visitation of the Virgin Mary] in Hejnice has three towers and three doors as depicted in Figure 2. The colored half circle and the faintly drawn character above the center doors depict a recessed statue of the Virgin Mary and infant Jesus. Figure 3 provides an actual photograph of this church for comparison.

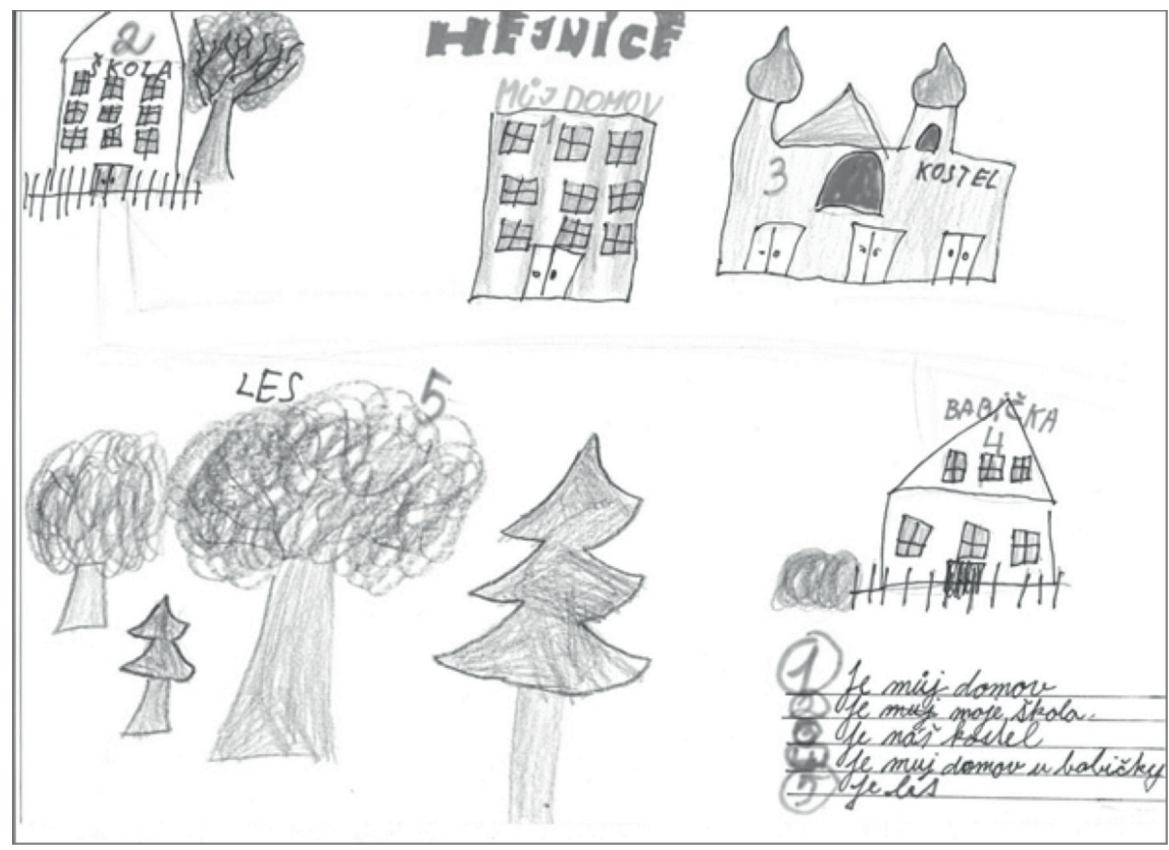

Fig. 2. Fourth-grade student in Hejnice

Translation: 1. můj domov - my home, 2. škola - school, 3. kostel - church, 4. babička - grandmother, 5. les - forest. List in the lower right: 1. It is my home; 2. It is my school; 3. It is our church; 4. It is my grandmother's home; 5. It is the forest 


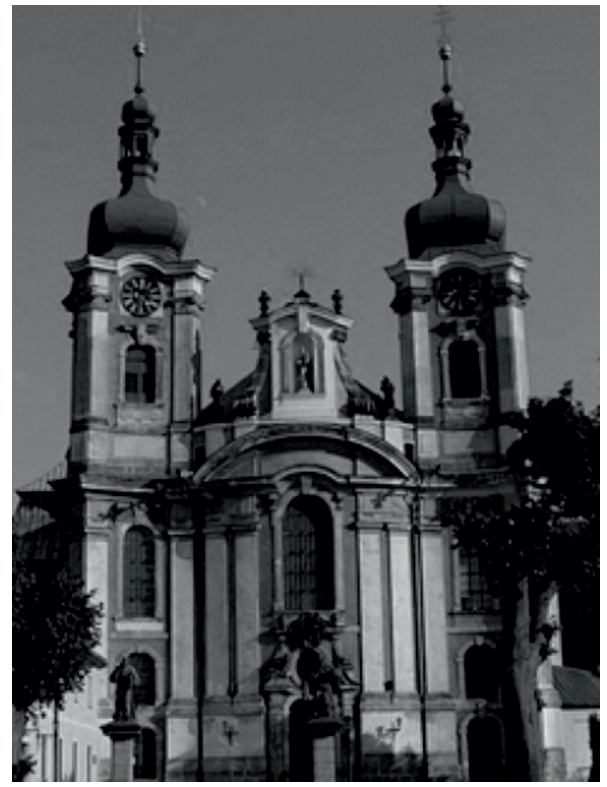

Fig. 3. Photograph of the Church of the Visitation of the Virgin Mary in Hejnice Source: Wikimedia Commons, Public Domain

The two distinct age groups involved in this study presented some interesting overall differences. It seems that fourth-grade students, in general, are not yet accustomed to the spatial organizations commonly present in published maps. They had a more difficult time arranging things spatially or depicting places and items to scale. Maps from eighth-grade students often looked much more like a traditional map, including street networks and a notion of scale (see Figure 4).

Figure 4 presents a map from an eighth-grade student in Karpacz. This map includes a street network and a number of different types of pathways. These appear to be sidewalks and stairways. Although this map's author has not marked a religious site as one of her/his important places, a church is depicted on the map - in the lower left with a cross on its triangular shaped steeple.

The next example of a map, Figure 5, is from an eighth-grade student in Krajná Pol'ana. This particular map, however, does not depict Krajná Pol'ana, but rather the nearby village of Hunkovce. The student demonstrates careful attention to detail in both the wooden church and the German cemetery, two elements of the village's sacral landscape. The actual wooden church in Hunkovce, Chrám Ochrany Presvätej Bohorodičky [Church of the Protection of the Mother of God], has an exterior that is divided into three distint sections just as it is on this map. The German cemetery is the burial place for many German soldiers that lost their lives in the Battle of Dukla Pass in 1944. The tombstones all have a cross shape. The cemetery also contains a large cross monument and an abundance of rock masonry. These various elements are apparent in Figure 5. 


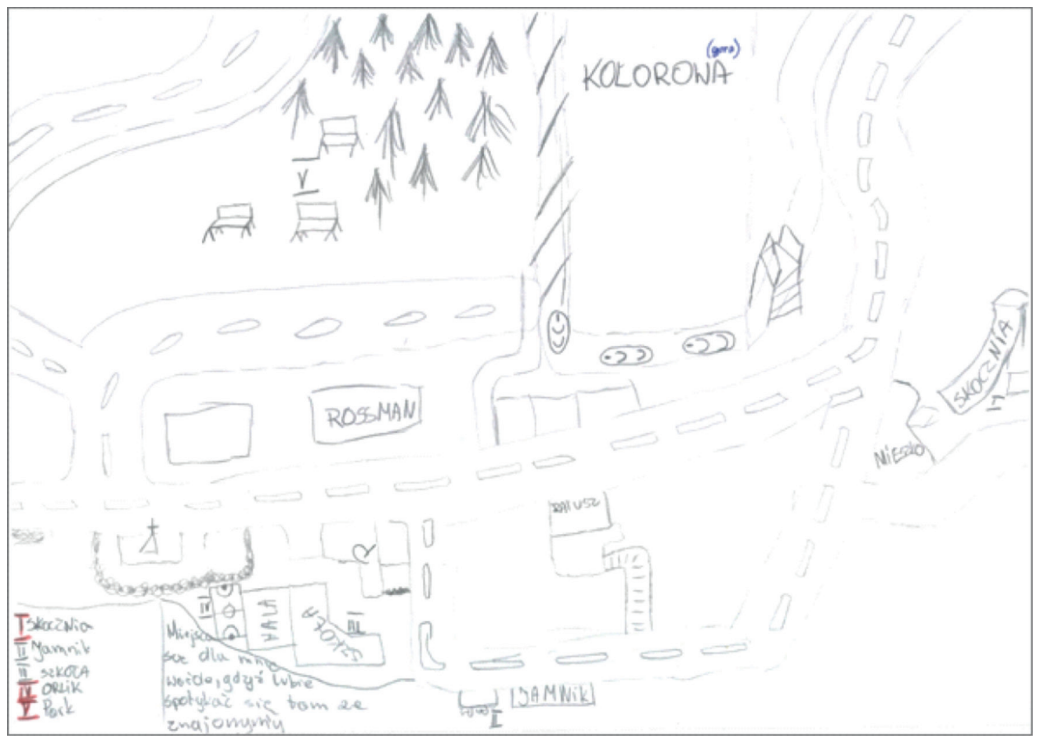

Fig. 4. Eighth-grade student from Karpacz

Translation: I. skocznia - ski jump, II. Jamnik - name for a store, III. szkola - school, IV. Orlik - sports field(?), V. Park. Text to the right of numbered list: Places important for me are those where I enjoy meeting with friends/acquaintances

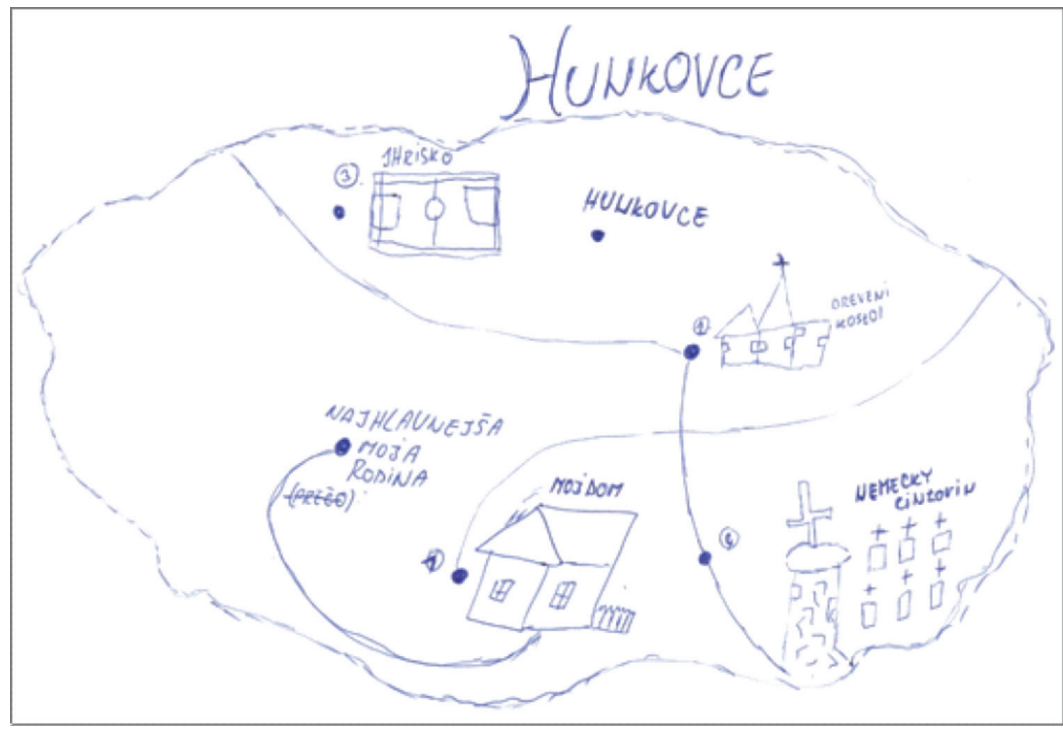

Fig. 5. Eighth-grade student in Krajná Pol'ana

Translation: 1. moj dom - my house, 2. Dreveni kostol - wooden church, 3. Ihrisko - playing field, 4. Nemecky cintorin - German cemetery. Additional text: Najhlavnejša moja rodina - most important is my family 
Some participants in the study expended more effort to explain why places depicted on their maps were important to them. The map shown in Figure 6, for example, from a student in Tylawa, had detailed statements describing the significance of each of the numbered sites. Next to number two it reads, "The church, because I go there on Sunday with my family to pray." The combination of a visual depiction of the church, drawn from memory, that depicts details of its architecture and a statement explaining the student's practice of regularly going to the church to pray make a powerful statement concerning this sacral landscape in the eyes of one beholder.

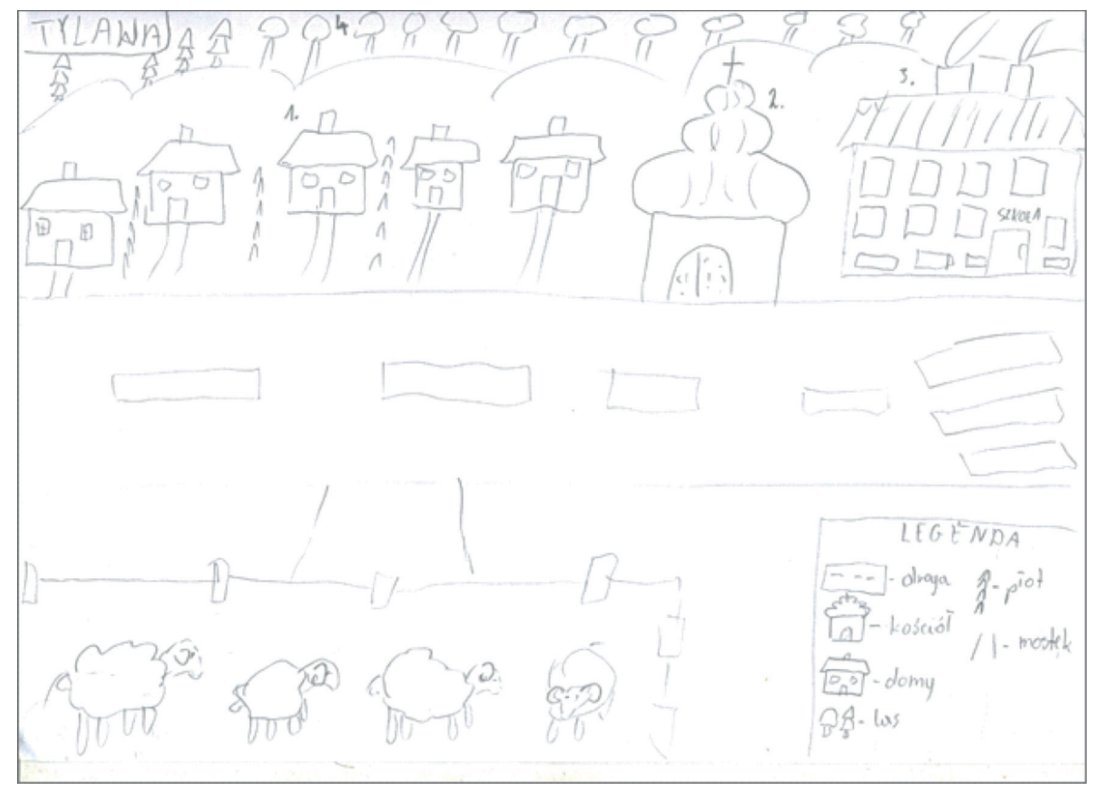

Fig. 6. Eighth-grade student from Tylawa

Translation of legend: droga - roadway, kościół - church, domy - houses, las - forest, płot - fence, mostek - bridge

The final map that we include - Figure 7 - is from a fourth-grade student in Ladomírová. It shows more of the landscape-oriented scenery that typifies the fourth-grade maps. The student's three important places are, in order of importance, the church, home and nature. This map looks quite impressive in colour, with its flowers, butterflies, mushrooms and fruit trees. The church in Ladomírová, Chrám svätého Michala [Church of St. Michael the Archangel], has a large and distinct bell tower that stands as a separate structure next to the actual church building. This explains the dual structure near the label kostol [church] and yet again demonstrates the significance of sacral landscapes to children within the respective local communities. 


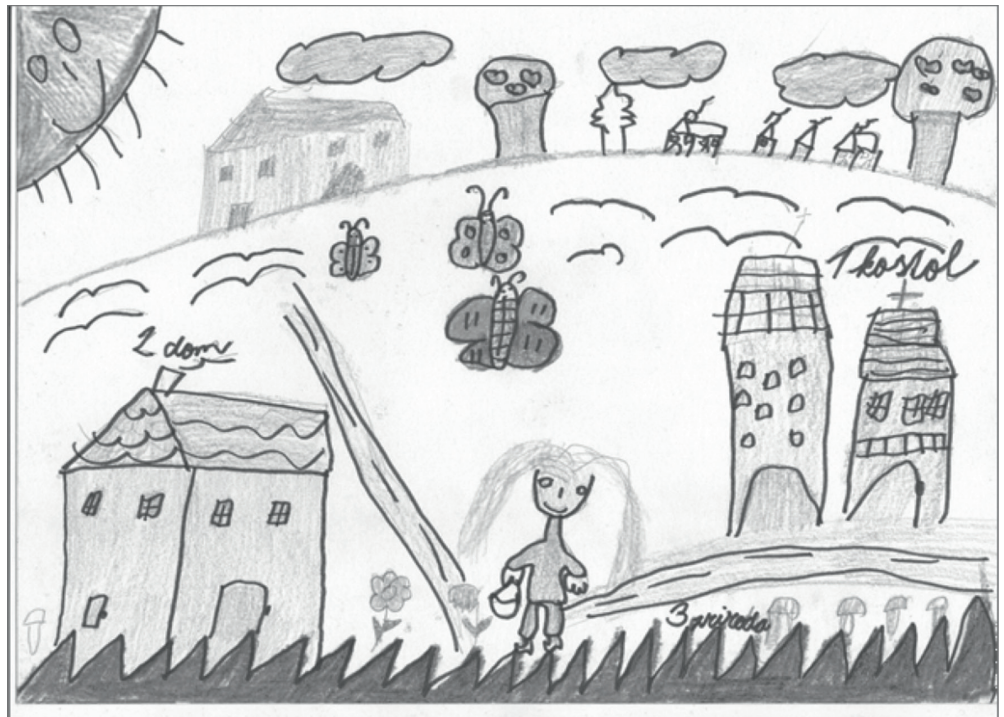

Fig. 7. Fourth-grade student from Ladomírová Translation: kostol - church, dom - house, priroda - nature

\section{Conclusion}

We structured this research study around two questions that we can now answer. First, do traditionally important religious sites have meaning for today's children? Yes, the inclusion of traditional religious sites on many of observed maps, even without being labelled as important, demonstrates the meaning that these sites have for children in a post-secular age. This particular study focuses on rural areas where the impacts of secularism and post-secularism are less evident. Using the same methods to research children's perceptions in urban areas of Central Europe would be an excellent follow-up to this research.

The second research question: Do perceptions of religious sites differ noticeably among children living in different model areas and on different sides of international borders? The study provides evidence to say that yes, perceptions of local religious sites are different both in the two distinct model areas and in the three countries of the study. Differences were also apparent among the three countries, with the Slovak communities showing the highest affinity for their religious sites, followed by Poland and then Czechia. We should point out here the potential fallacy in comparing these results directly to one another. Every village and town is unique in myriad ways, as are the children that inhabit said villages and towns. So, while comparing the results for similar-sized towns within proximate areas is insightful, it should not be interpreted in the same way as hard scientific data. 
The methods used in this study have great potential for a wide variety of additional studies. This research focused on children's perceptions of religious sites. Any number of topics beyond religion could be examined in much the same way; retail centers, recreational opportunities or natural landmarks, to name a few. Different age groups or other segments of a population could also be targeted and/or compared one with another.

After viewing several of these student-created cognitive maps, it becomes clear that they are communicating a great deal of information regarding local territorial identity. Accurate portrayals of unique details of local sacral landscapes demonstrate that children are, in many cases, utilizing religious sites as building blocks of their own community identity. In addition, numerically ordered indications of the importance of specific locations depicted on their maps provide children another avenue to express preferences and describe their own hometown. Many children singled out churches and cemeteries as important places within their hometowns.

\section{References}

Bilska-Wodecka E., 2005, Poland. Post-communist religious revival, [in:] Knippenberg H. (ed.), The changing religious landscape of Europe, Het Spinhuis, Amsterdam: $120-144$.

Bilska-Wodecka E., 2006, From multi-confessional to mono-confessional state. Statechurch relations in Poland following World War II, "GeoJournal", 67 (4): 341-355.

Brace C., Bailey A.R., Harvey D.C., 2006, Religion, place and space: A framework for investigating historical geographies of religious identities and communities, "Progress in Human Geography", 30(1): 28-43, https://doi.org/10.1191/0309132506ph589oa

Chromý P., Jančák V., Marada M., Havlíček T., 2011, Venkov - žitý prostor: regionální diferenciace percepce venkova představiteli venkovských obcí v Česku [Rural Areas - Living Space: Regional Differencies in the Perceptions of Representatives of Rural Municipalities in Czechia Regarding Rural Areas], "Geografie", 116(1): 23-45.

Ellard C., 2015, Places of the Heart the Psychogeography of Everyday Life, Bellevue Literary Press, New York.

European Union (ed.), 2005, Special Eurobarometer 225: Social values, science and technology.

Hammond P., 1988, Religion and the persistence of identity, "Journal of Scientific Study of Religion", 27(1): 1-11.

Hamplová D., 2013, Náboženství v české společnosti na prahu 3. tisiciletí [Religion in the Czech Society on the threshold of the third millennium], Karolinum, Prague.

Havlíček T., 2014, Development and Transformation of Religious Landscape in Prague after the Fall of Communism, "Prace Geograficzne", 137: 51-67.

Havlíček T., Hupková M., 2008, Religious landscape in Czechia: New structures and trends, "Geografie", 113(3): 302-319. 
Havlíček T., Hupková M., 2013, Sacred structures in the landscape: The case of rural Czechia, "Scottish Geographical Journal", 129(2): 100-121, https://doi.org/10.1080/1 4702541.2012.754931

Havlíček T., Hupková M., Smržová, K., 2009, Changes in the geographical distribution of religious heterogeneity in Czechia during the transformation period, „AUC Geographica”, 44(1-2): 31-47.

Havlíček T., Klingorová K., 2018, City with or without God? Features of post-secularism in religious landscape of post-communist Prague, "Social \& Cultural Geography", 19(6): 789-811, https://doi.org/10.1080/14649365.2017.1312696

Hemming P.J., Madge N., 2011, Researching children, youth and religion: Identity, complexity, agency, "Childhood", 19(1): 38-51.

Henkel R., 2014, The changing religious space of large Western European cities, „Prace Geograficzne", 137: 7-15, https://doi.org/10.4467/20833113PG.14.006.2151

King P.E., 2003, Religion and Identity: The Role of Ideological, Social and Spiritual context, "Applied Development Studies", 7(3): 197-204, https://doi.org/10.1207/ S1532480XADS0703_11

Klingorová K., 2016, Feministické geografie náboženství: křest’anství v každodenním životě mladých žen [Feminist geographies of religion: Christianity in everyday life of young women], "Geografie", 121(4): 612-631.

Očovský Š., 1995, Änderungen der religiösen Struktur der Bevölkerung in der Slovakei im 20. Jahrhundert, [in:] Rinschede G., Vossen J. (eds.), Beiträge zur Religionsgeographie 1995, "Geographia Religionum”, 10: 21-42, Dietmar Reimer, Berlin.

Pew Research Center (ed.), 2012, The Global Religious Landscape, http://www.pewforum. org/2012/12/18/global-religious-landscape-exec/

Potančoková M., Berghammer C., 2015, Urban Faith: Religious Change in Vienna and Austria from 1986 to 2013, [in:] Pokorny L., Hödl G. (eds.), Religion in Austria, Volume 2, Praesens, Vienna.

Reeves D., 2015, Religious themes in Central European postage stamps, 2006-2010, "Journal of Cultural Geography", 32(2): 169-194, https://doi.org/10.1080/08873631. 2015.1021093

Tomka M., 2005, Church, State and Society in Central Europe, The Council for Research in Values and Philosophy, Washington, D.C.

Wikimedia Commons, 2006, Bazilika Navštivení Panny Marie.jpg., https://commons. wikimedia.org/wiki/File:Bazilika_Nav\%C5\%A1t\%C3\%ADven\%C3\%AD_Panny_ Marie.jpg. [Accessed 15 Apr. 2017].

Wilford J., 2010, Sacred archipelagos: Geographies of secularization, "The Sage Handbook of Human Geography", 34(3): 328-348, https://doi.org/10.1177/03091325 09348558

Zachar Podolinska T., Tížik M., Majo J., 2019, Religiosity in Slovakia: Structure, Dynamics and Spatial Diversification, "Central European Journal of Contemporary Religion", 1: 1-33, https://doi.org/10.14712/25704893.2019.1 


\section{POSTRZEGANIE PRZEZ DZIECI MIEJSC KULTU RELIGIJNEGO NA TERENACH WIEJSKICH EUROPY ŚRODKOWEJ: STUDIA PRZYPADKÓW NA POGRANICZU CZESKO-POLSKIM I POLSKO-SLOWACKIM}

Zarys treści: Niniejsze opracowanie koncentruje się na badaniu lokalnej tożsamości dzieci mieszkających w małych miastach na pograniczu Czech, Polski i Słowacji. Mapy poznawcze, sporządzane przez uczniów szkół podstawowych w gminach położonych w pobliżu granic państwowych, pozwalają zbadać znaczenie lokalnych miejsc kultu religijnego w umysłach młodych ludzi. Badanie to z powodzeniem analizuje codzienne interakcje między badanymi a ich lokalnym krajobrazem. Ma na celu podkreślenie religijnych elementów tożsamości lokalnej.

Metody zastosowane w badaniach prezentują bardziej humanistyczne i jakościowe podejście, rzucając światło na codzienne doświadczenia dzieci mieszkających na wsi. Mapy szczegółowej lokalizacji miejsc kultu religijnego szkicowane przez dzieci są doskonałym narzędziem na przeniesienie badań poza sferę ,oficjalnie sakralną”. Metody te pozwalają również na wymieszanie na mapie elementów zarówno pasywnych (miejsca sakralne na mapie poznawczej), jak i aktywnych, zaliczających dany obiekt religijny do trzech najważniejszych preferencji elementów religijnych, w ramach lokalnej tożsamości terytorialnej.

Niniejsze badanie pokazuje, w jaki sposób dzieci wykorzystują elementy lokalnego krajobrazu religijnego do konstruowania i rekonstruowania tożsamości społecznej. Dwie słowackie gminy wykazały największą sympatię do elementów religijnych. Polskie gminy uplasowały się pośrodku, a dwie czeskie gminy uzyskały najniższe oceny pod względem miejsc kultu religijnego uznanych za ważne dla uczestników badania.

Słowa kluczowe: percepcja dzieci, miejsca kultu religijnego, obszary wiejskie Europy Środkowej, tożsamość religijna.

Mgr. Daniel Reeves

Charles University

Faculty of Science

Department of Social Geography and Regional Development e-mail: danvreeves@gmail.com

RNDr. Tomáš Havlíček, Ph.D.

Charles University

Faculty of Science

Department of Social Geography and Regional Development e-mail: tomas.havlicek@natur.cuni.cz 